\title{
Evidence of a role for neuropeptide $Y$ and monoamines in mediating the appetite-suppressive effect of $\mathbf{G H}$
}

\author{
X Wang, J R Day ${ }^{1}$, Y Zhou, J L Beard ${ }^{2}$ and R Vasilatos-Younken \\ Department of Poultry Science, Pennsylvania State University, University Park, Pennsylvania 16802, USA \\ ${ }^{1}$ Department of Biology, Pennsylvania State University, University Park, Pennsylvania 16802, USA \\ ${ }^{2}$ Department of Nutrition, Pennsylvania State University, University Park, Pennsylvania 16802, USA \\ (Requests for offprints should be addressed to R Vasilatos-Younken; Email: rxv@psu.edu)
}

\begin{abstract}
Among the many responses to GH administration is suppression of voluntary feed intake (FI) in some species, attributed to improvement in the efficiency of nutrient utilization and, therefore, reduced need for ingested substrates. Commercial broiler chickens have been genetically selected for generations for rapid growth, realized largely via the major correlated response of increased voluntary feed consumption. Neuropeptide Y (NPY) and monoamines play very important roles in the central regulation of feeding. Preliminary studies from our laboratory suggest that the appetite-suppressive effect of GH may be independent of its actions as a repartitioning agent, and may involve alterations in NPY expression at the pre-translational level. The purpose of this investigation was to explore the dose-response nature of the appetite-suppressive effect of GH in juvenile broilers, and the possible involvement of NPY and monoamines in this process.
\end{abstract}

A GH dose-response study was conducted using 8 -week-old female broilers infused i.v. with $\mathrm{GH}$ in a pulsatile pattern for 7 days at $0,10,50,100$ or $200 \mu \mathrm{g} / \mathrm{kg}$ body weight per day. Hypothalamic NPY and epinephrine (EP) concentrations decreased in a dose-related manner with $\mathrm{GH}$. At the highest dosage, voluntary FI decreased $19 \%(P<0.05)$ and hypothalamic NPY mRNA decreased approximately $50 \%$ in the infundibular nuclei and midline region $(P<0 \cdot 0001)$. In contrast, birds pairfed to the high-GH dosage group did not differ from controls, verifying that changes in NPY and monoamines were not secondary to reduced FI. We conclude that hypothalamic NPY and EP are likely candidates to explore further as mediators of the appetite-suppressive effect of $\mathrm{GH}$.

Journal of Endocrinology (2000) 166, 621-630

\section{Introduction}

Growth hormone $(\mathrm{GH})$ is a major anabolic agent with effects on protein, fat and carbohydrate metabolism. Numerous investigators have demonstrated that GH alters voluntary feed intake (FI), but there are marked species differences. A consistent effect on reducing FI is observed in the pig (Klindt et al. 1998), and GH attenuates the elevated food consumption exhibited during binge-eating in anorexic/bulemic patients (Vaccarino et al. 1994). Alternatively, GH treatment increases FI in rats (Azain et al. 1995). The mechanisms underlying the effects of $\mathrm{GH}$ on FI have not been explored.

The domestic chicken raised for meat purposes (broiler) has been intensely selected over generations for increased body weight at early ages, derived primarily from the major correlated response of increased voluntary feed consumption (Pym \& Nicholls 1979). Contemporary generations of this model display extreme hyperphagia, which results in obesity and attendant health problems similar to the human population (e.g. skeletal, reproduc- tive, cardiovascular), if feed is unrestricted beyond the juvenile period of development. In fact, the ability to regulate energy intake is absent in the broiler (Siegel \& Wisman 1966).

$\mathrm{GH}$ is secreted in a well-characterized pulsatile pattern in the broiler, with high amplitude peaks occurring at 90-min intervals during early post-hatch development, when growth velocity is maximal (Vasilatos-Younken \& Zarkower 1987). In contrast, with increasing age, baseline concentrations decrease and the amplitude of secretory peaks diminishes markedly, so that plasma GH is barely detectable by the late post-hatch period, when birds are still juvenile in development. Research from our laboratory (Vasilatos-Younken 1995) indicates that $\mathrm{GH}$ enhancement during the late post-hatch period, either by direct administration of $\mathrm{GH}$ or stimulation of endogenous $\mathrm{GH}$ secretion via GH-releasing factor administration, depresses voluntary FI, similar to the human. In addition, evidence suggests that birds and mammals have similar feeding control mechanisms (Denbow 1985). 
Appetite regulation is very complex, and multiple brain structures and neurotransmitters are known to be involved. The hypothalamus, believed to have an important role in FI regulation, is rich with neurotransmitters and neuropeptides. Among these, neuropeptide Y (NPY) is a potent stimulator of feeding, and is highly conserved among species (Blomqvist et al. 1992). The 36 amino acid peptide differs by only a single amino acid (Ser7) in the chicken versus the rat and human, the latter of which are identical. Similar to its action in mammals (Leibowitz 1989), NPY has a robust stimulatory effect on FI in the chicken when administered intracerebroventricularly (Kuenzel et al. 1987a). Most of the metabolic effects of NPY appear to be centrally mediated in the hypothalamus (Sahu et al. 1988, Leibowitz 1989), with the paraventricular nucleus (PVN) principally involved. The PVN receives rich afferents of NPY immunoreactive nerve endings from epinephrine (EP)-containing neurons in the medulla (C1 or C2), norepinephrine (NE)-containing neurons in the medulla (A1) and dorsal pons (A6), and non-catecholaminergic neurons in the infundibular nuclei (IN) (McDonald 1988). The extensive coexistence of NPY and monoamines in the central nervous system (Sawchenko et al. 1985) suggests that NPY and monoamines may interact in the hypothalamus to regulate FI.

Monoamines, namely NE, EP, dopamine (DA), and serotonin $(5-\mathrm{HT})$, are believed to have potent and varied effects on eating behavior in the rat, as well as in a variety of other species (Leibowitz 1980, 1989). Hypothalamic stimulation with $\mathrm{NE}$ or EP has long been known to potentiate feeding in mammals (Leibowitz 1989) and in the chicken (Denbow et al. 1981). This stimulatory effect is anatomically localized, predominantly to the PVN, and it is mediated via $\alpha 2-$ rather than $\alpha 1$-type receptors located on post-synaptic membranes (Leibowitz \& Brown 1980). In contrast, intraventricular injection of 5-HT suppresses feeding behavior (Denbow et al. 1981, Leibowitz 1985). Bilateral hypothalamic injection of DA induces depression of FI expressed as reduced meal size in the rat (Yang et al. 1997), while intracerebral injection of DA has no effect on FI in the chick (Denbow et al. 1981).

Recently, GH has been identified as a possible regulator of NPY gene expression. Treatment of rats with GH induces $\mathrm{c}$-fos gene expression in the NPY-containing neurons in the arcuate nucleus (Kamegai et al. 1994). Hypophysectomy significantly decreases NPY mRNA levels, and $\mathrm{GH}$ treatment restores these levels to those of intact rats (Chan et al. 1996). Hypothalamic monoamines are reported to be affected by $\mathrm{GH}$, and may participate in GH autoregulation (Lea \& Harvey 1993). The present experiment was designed to investigate the dose-response nature of $\mathrm{GH}$ on voluntary $\mathrm{FI}$, and the possible involvement of NPY and monoamines in this process.

\section{Materials and Methods}

\section{Animal experiments}

All animal procedures were approved by Pennsylvania State University Institutional Animal Care and Use Committee under protocol no. 89R1389 G197.

Over the developmental period prior to sexual maturity, plasma GH concentrations in broilers similar to those used in the present study can range from $<10.0 \mathrm{ng} / \mathrm{ml}$ (baseline troughs) to over $100 \mathrm{ng} / \mathrm{ml}$ (secretory peaks) (VasilatosYounken \& Zarkower 1987, Johnson et al. 1987, R Vasilatos-Younken, unpublished data). A series of dosages $(0,10,50,100$ and $200 \mu \mathrm{g} / \mathrm{kg}$ body weight (BW) per day) was chosen that was calculated to result in circulating concentrations over this range, and to include the approximate dosage of chicken $\mathrm{GH}(\mathrm{cGH})$ that was estimated in a previous study to be maximally effective in terms of metabolic responses $(123 \mu \mathrm{g} / \mathrm{kg}$ BW per day; VasilatosYounken et al. 1988). Birds were selected to be 8 weeks of age at the initiation of infusions, because at this time endogenous GH secretion is low and circulating concentrations are barely detectable $(<1.0 \mathrm{ng} / \mathrm{ml})$. This was to avoid superimposing exogenous hormone pulses on preexisting (endogenous), high-amplitude secretory peaks, as would occur at very young ages, and that would result in a refractory state.

Seven-week-old female broilers were surgically prepared with jugular vein catheters as previously described (Cravener \& Vasilatos-Younken 1989). Birds were allowed 3-6 days of postoperative recovery, and normal, pre-surgical behavior, FI and BW gain were confirmed prior to initiation of infusions. When birds were 8 weeks of age (late post-hatch), recombinant cGH (Lucky Biotech, Seoul, Republic of Korea) was infused in a pulsatile pattern for 7 days at one of five dosages $(0,10,50,100$ or $200 \mu \mathrm{g} / \mathrm{kg}$ BW per day) (ten birds per dosage), and FI was monitored daily. The infusion protocol has been described previously (Vasilatos-Younken et al. 1988), and is based on a pulse interval $(90 \mathrm{~min})$ and duration $(60 \mathrm{~min})$ that replicate the endogenous pattern of $\mathrm{GH}$ secretion in young, rapidly growing broilers. Infusions were conducted in two experimental replicates over time, approximately 3 weeks apart, with every treatment included in each experiment.

To control for possible contributions of reduced FI on measured responses, additional, pair-fed groups for $\mathrm{GH}$ treatments were established. Pair-feeding of vehicleinfused birds was accomplished by assigning a level of feed restriction to match the amount of feed consumed by the GH treatment groups which exhibited significantly reduced FI in comparison to controls.

FI was measured daily throughout the study. Blood samples were collected on the final day of infusion, immediately following a GH pulse, to determine GH peak amplitudes achieved by infusion. Heparinized blood samples were placed on ice and processed immediately. 
Plasma was obtained by centrifugation, aliquoted to multiple vials, and stored at $-70{ }^{\circ} \mathrm{C}$ until assayed. Plasma GH was determined by a homologous $\mathrm{cGH}$ radioimmunoassay (RIA) as previously described (Vasilatos-Younken 1986). Animals were killed by rapid decapitation. Brains were removed and half of each brain was frozen in isopentene cooled by dry ice to $-30{ }^{\circ} \mathrm{C}$ and stored at $-80{ }^{\circ} \mathrm{C}$ until NPY hybridization histochemistry was conducted. The other halves were dissected, using the atlas of Kuenzel \& Masson (1988). The hypothalamus and the medulla were removed and immediately weighed, frozen in liquid nitrogen, and stored at $-80{ }^{\circ} \mathrm{C}$ for NPY RIA assay and monoamine detection.

\section{NPY RIA}

Synthetic NPY standard (rat/human) from Peninsula Laboratories (Belmont, CA, USA) was used for standard preparations and for the preparation of labeled NPY. Radioactive ${ }^{125} \mathrm{I}$ was purchased from Amersham International (Arlington Heights, IL, USA). The primary (polyclonal) antibody $\left(\mathrm{Ab}_{1}\right)$ was rabbit anti-rat NPY $(3-8)$ serum, and was generously donated by $\operatorname{Dr}$ Marvin $\mathrm{R}$ Brown (Alanex Corporation, San Diego, CA, USA). Anti-rat NPY(3-5) was previously characterized (Allen et al. 1991) and did not cross-react with any related peptides, including peptide YY and pancreatic peptide.

NPY was labeled with ${ }^{125} \mathrm{I}$ using the chloramine- $\mathrm{T}$ method (Hunter \& Greenwood 1962). The iodination procedure was carried out on ice with chilled reagents. Briefly, $5 \mu \mathrm{g}$ NPY dissolved in $6 \mu$ l double-distilled $\mathrm{H}_{2} \mathrm{O}$ $\left(\mathrm{ddH}_{2} \mathrm{O}\right)$ was labeled with $1 \mathrm{mCi} \mathrm{Na}-{ }^{125} \mathrm{I}$ and $7 \mu \mathrm{g}$ chloramine- $\mathrm{T}$ dissolved in sodium phosphate buffer (50 mM NaPO $4,0.9 \%$ NaCl, $25 \mathrm{mM}$ EDTA, 0.1 g/l thimerosal and $0 \cdot 25 \%$ bovine serum albumin (BSA), $\mathrm{pH}$ $7 \cdot 4)$. The reaction time was $18 \mathrm{~s}$. The reaction was ended by adding $5 \mu \mathrm{l}$ sodium metabisulfite solution $(10 \mathrm{mg} / \mathrm{ml}$ in sodium phosphate buffer). Separation of the reaction mixture was achieved by gel filtration on a G-25 PD-10 column with a bed height of $5 \mathrm{~cm}$ (Pharmacia, Uppsala, Sweden), and eluted with sodium phosphate buffer. Forty fractions of $2 \mathrm{ml}$ were collected. The peak fraction was diluted and used for immunoassay detection.

Hypothalamic samples were homogenized in $300 \mu \mathrm{l}$ $0 \cdot 1 \mathrm{M}$ sodium acetate buffer containing 3-4-dihydroxybenzylamine $\mathrm{HBr}$ (DHBA; $48 \mathrm{ng} /$ tube) and ascorbic acid oxidase (325 ng/tube). The samples were then centrifuged at $10000 \mathrm{~g}$ for $10 \mathrm{~min}$ at $4{ }^{\circ} \mathrm{C}$ and aliquots of the supernatant were removed for monoamine determination and NPY assay. For NPY assay, $120 \mu l$ hypothalamic extract were re-extracted with $\mathrm{C}_{18}$ Sep-Pak columns (Peninsula Laboratories). The samples were concentrated by lyophilization and brought to $120 \mu \mathrm{l}$ with assay buffer. Plasma samples $(1 \mathrm{ml})$ were also extracted as for hypothalamic samples. The final volume for plasma samples was $300 \mu \mathrm{l}$.
The NPY assay was carried out at $\mathrm{pH} 7 \cdot 4$ using phosphate buffer $\left(50 \mathrm{mM} \mathrm{NaPO}_{4}, 0.9 \% \mathrm{NaCl}, 25 \mathrm{mM}\right.$ EDTA, $0 \cdot 1 \mathrm{~g} / 1$ thimerosal, $0 \cdot 25 \% \mathrm{BSA}, \mathrm{pH} 7 \cdot 4)$. Final dilution of $A b_{1}$ (1:45 000 in phosphate buffer) was chosen to achieve a maximal binding of $30-40 \%\left[{ }^{125} \mathrm{I}\right] \mathrm{NPY}$. Standards consisted of synthetic human NPY prepared in phosphate buffer. The initial incubation mixture, containing $10 \mu \mathrm{l}$ of a 1:10 dilution of hypothalamic extract $(50 \mu \mathrm{l}$ for plasma samples), $490 \mu \mathrm{l}$ assay buffer ( $450 \mu \mathrm{l}$ for plasma) and $100 \mu \mathrm{l}$ diluted antibody, was incubated for $48 \mathrm{~h}$ at $4{ }^{\circ} \mathrm{C}$. On the third day, $\left[{ }^{125} \mathrm{I}\right] \mathrm{NPY}$ (approximately 5000 c.p.m., in $100 \mu$ l phosphate buffer per tube) was added, and samples were incubated for $24 \mathrm{~h}$ at $4{ }^{\circ} \mathrm{C}$. On the fourth day, $50 \mu \mathrm{l}$ of a 1:20 dilution of normal rabbit serum and $100 \mu \mathrm{l}$ of a 1:10 dilution of goat anti-rabbit IgG were added and the mixture incubated for $24 \mathrm{~h}$. The assay was terminated by addition of $2 \mathrm{ml}$ ice-cold sodium phosphate buffer $\left(0 \cdot 01 \mathrm{M} \mathrm{NaPO}_{4}\right.$ and $\left.0 \cdot 14 \mathrm{M} \mathrm{NaCl}\right)$. Tubes were centrifuged at $2000 \mathrm{~g}$ for $30 \mathrm{~min}$, supernatants decanted, and radioactivity in the pellet measured in a gamma counter (Pharmacia LKB Nuclear Inc, Gaithersburg, MA, USA). The sensitivity of the assay was $250 \mathrm{pg} / \mathrm{ml}$. Interand intra-assay coefficients of variation were $20 \%$ and $14 \%$ respectively, and the concentration at $50 \%$ of maximal binding was $1.7 \mathrm{ng} / \mathrm{ml}$.

\section{In situ hybridization for NPY}

Tissue preparation Using the chicken atlas of Kuenzel \& Masson (1988) as an anatomical guide, coronal brain sections $(10 \mu \mathrm{m}$ thick) were obtained with a cryostat (Leica CM1900; Leica Instruments GmbH, Mussloch, Germany). Every fifth section was thaw-mounted onto poly-L-lysine subbed Superfrost/Plus Microscope Slides (Fisher Scientific, Pittsburgh, PA, USA). Slides were stored in air-tight boxes at $-80{ }^{\circ} \mathrm{C}$ until hybridization histochemistry was conducted.

Probe preparation A 511 bp pre-proNPY cDNA fragment, containing the full-length rat NPY sequence, was inserted into the EcoRI site of Bluescribe M13(-) vector (Stratagene, La Jolla, CA, USA). The probe was kindly provided by Dr Steven Sabol (Department of Health and Human Services, National Institute of Health, Bethesda, MD, USA) (Higuchi et al. 1988). E. coli XL-1 blue competent cells (Stratagene) were transformed by electroporation with E. coli pulser (Bio-Rad, Hercules, CA, USA). Pulse time was approximately $5 \mathrm{~ms}$, and volts were $1.8 \mathrm{kV}$. The plasmid, which contained two FspI sites, was linearized overnight at $37^{\circ} \mathrm{C}$ with FspI (1.25 unit/ $\mu \mathrm{g}$ DNA) (New England Biolabs, Beverly, MA, USA) for antisense RNA, and overnight at $37^{\circ} \mathrm{C}$ with HindIII (2.5 unit/mg DNA) (Promega Biotech, Madison, WI, USA) for sense-strand RNA. The linearized plasmid DNA was transcribed with $\left[{ }^{35} \mathrm{~S}\right]$ thio-UTP (New England Nuclear Research Products, Boston, MA, USA) at a 
concentration of $50 \mu \mathrm{M}$, using T7 and T3 RNA polymerase (Promega Biotec) for sense and antisense probes respectively. Residual DNA was removed by digestion with DNAase (Promega Biotec), and the cRNA probes were purified on a Nensorb column (Stratagene).

The specificity of the rat NPY probe for detection of chicken NPY message in brain tissues has been previously verified by Northern analysis, which demonstrated that a ${ }^{32}$ P-labeled riboprobe hybridized to complimentary, single-stranded chicken NPY mRNA identically as for rat, and showed the presence of a single $0.8 \mathrm{~kb}$ transcript on autoradiography (X Wang, J R Day \& R VasilatosYounken, unpublished observations).

Single-label in situ hybridization histochemistry for NPY mRNA Using the ${ }^{35} \mathrm{~S}$-labeled riboprobe complementary to NPY mRNA, in situ hybridization was performed as previously described (Day et al. 1990). In brief, after fixation in $4 \%$ paraformaldehyde (Sigma, St Louis, MO, USA) in phosphate-buffered saline (137 mM NaCl, $2.7 \mathrm{mM} \mathrm{KCl}, 4 \cdot 3 \mathrm{mM} \mathrm{Na} 2 \mathrm{HPO}_{4} \cdot 7 \mathrm{H}_{2} \mathrm{O}$ and $\left.1.4 \mathrm{mM} \mathrm{KH}_{2} \mathrm{PO}_{4}, \mathrm{pH} 7 \cdot 5\right)$, tissue sections were rinsed in phosphate buffer and pretreated with $0 \cdot 25 \%$ acetic anhydride (Fisher Scientific) in $0.1 \mathrm{M}$ triethanolamine $(\mathrm{pH} 8)$ for $10 \mathrm{~min}$. The slides were dehydrated through a series of ethanol baths $(50-100 \%)$ and air-dried. The ${ }^{35}$ S-labeled probe $(5000000$ c.p.m./section) was applied in a hybridization buffer containing $50 \%$ formamide (Fisher Scientific), $10 \%$ dextran sulfate (Sigma), $5 \times$ Denhardt's $(0.5 \mathrm{~g}$ Ficoll, $0.5 \mathrm{~g}$ polyvinylpyrrolidone, $0.5 \mathrm{~g}$ BSA and $\mathrm{H}_{2} \mathrm{O}$ to $\left.500 \mathrm{ml}\right), 4 \times \mathrm{SSC}\left(0.6 \mathrm{M} \mathrm{NaCl}\right.$ and $0.06 \mathrm{M} \mathrm{Na}_{3}$ citrate. $\left.2 \mathrm{H}_{2} \mathrm{O}, \mathrm{pH} 7 \cdot 0\right), 25 \mu \mathrm{g} / \mathrm{ml}$ poly A and poly C sulfate (Sigma), $100 \mathrm{mM}$ dithiothreitol (Fisher Scientific) and $0.25 \mathrm{mg} / \mathrm{ml}$ yeast transfer RNA (Sigma). Coverslips were applied and the sections were incubated for $3 \mathrm{~h}$ in a humidified chamber at $50{ }^{\circ} \mathrm{C}$. After hybridization, the slides were treated with $20 \mu \mathrm{g}$ RNase-A (Sigma) at $37^{\circ} \mathrm{C}$ for $30 \mathrm{~min}$ and washed at high stringency in $50 \%$ formamide, $0.5 \mathrm{M}$ $\mathrm{NaCl}, 50 \mathrm{mM}$ sodium phosphate (equal volumes of $1 \mathrm{M}$ $\mathrm{NaH}_{2} \mathrm{PO}_{4}$ and $1 \mathrm{M} \mathrm{Na}_{2} \mathrm{HPO}_{4}$ ) and $1 \% \beta$-mercaptoethanol (Sigma) at $55^{\circ} \mathrm{C}$ for $30 \mathrm{~min}$. Sections were then dehydrated for $3 \mathrm{~min}$ each in a series of ethanol baths (50-100\%) and air-dried. The slides were dipped in undiluted Kodak NTB-2 emulsion (VWR, Buffalo Grove, IL, USA) that had been heated to $45^{\circ} \mathrm{C}$ in a water bath for $45 \mathrm{~min}$, and then air-dried. Sections were exposed for 20 days at $4{ }^{\circ} \mathrm{C}$. Slides were then developed with Kodak D-19, counterstained with cresyl violate (Sigma), dehydrated through a $50-100 \%$ ethanol series, and coverslips were applied.

Sections containing the desired region were blindly analyzed by a computer-assisted automated image processing system (Image-1; University Imaging, West Chester, PA, USA) at $1250 \times$ in order to estimate grain density. Grain density was expressed as a percentage of the cell area occupied by grains. Background counts were subtracted from each labeled cell count. A cell was considered labeled only if the density was at least five times greater than the background, and was overlying a counterstained nucleus. Background measurements were taken from emulsioncoated regions of the slides where no tissue was present.

\section{HPLC determination of monoamines}

The concentrations of amines (NE, EP, DA, 5-HT) and amine metabolites (dihydroxyphenylacetic acid (DOPAC), homovanillic acid (HVA) and 5-hydroxyindoleacetic acid (5-HIAA)) in supernatants (collected after a 10-min centrifugation at $10000 \mathrm{~g}, 4{ }^{\circ} \mathrm{C}$ ) were determined by reversephase HPLC (BAS200A; Bioanalytical System, Lafeyette, IN, USA) and electrochemical detection (LC4B detector; Bioanalytical Systems). The samples (spiked with DHBA as an internal standard) were separated on a reverse-phase, $100 \times 3.2 \mathrm{~mm}$ column of Phase II ODS $3 \mu \mathrm{m}$ silica particles (MF6213; Bioanalytical Systems), which was eluted with $2.5 \%(\mathrm{v} / \mathrm{v})$ acetonitrile in $\mathrm{ddH}_{2} \mathrm{O}$ in the presence of $0.127 \mathrm{M}$ monochloroacetic acid, $0.03 \%(\mathrm{w} / \mathrm{v})$ octyl sodium sulfate and $0.65 \mathrm{mM}$ EDTA- $\mathrm{Na}_{2}$. The flow rate was $0.8 \mathrm{ml} / \mathrm{min}$ or $1 \mathrm{ml} / \mathrm{min}$ and the amines and metabolites of interest were quantified by peak height. Peak identifications were accomplished by the evaluation of retention times using external standards. A peak in an unknown sample which fell within the range of $95-105 \%$ of the external standard retention time for a given monoamine was accepted.

\section{Statistical analysis}

Plasma GH data displayed heterogeneity of variance and were transformed to natural $\log$ scale prior to statistical evaluation. Dose-response data were analyzed using regression analysis, and signficant effects (linear, quadratic and/or cubic) were retained in the final model for each response. Pair-feeding data were analyzed by analysis of variance according to the model for a completely randomized design. For assessment of treatment effects on FI, each bird served as its own control by calculating the percentage change in average daily FI (g/kg BW per day) for the final 3 days of infusion, relative to the same bird's preinfusion FI (average of the 3 days immediately preceding initiation of treatments). Because FI normally decreases as broilers mature (National Research Council (US) 1994), and this was observed in all birds across treatment groups prior to infusion, FI change was corrected for the average normal decline observed in the controls.

For informational purposes, arithmetic least squares means (LSM) are presented as \pm S.E.M. of the LSM in Tables and Figures for all data.

\section{Results}

All birds were carefully monitored during the experiments to assess behavior, health status and, upon termination, appearance of internal organs. Birds exhibited normal 
Table 1 Plasma GH and NPY concentrations, and hypothalamic NPY concentrations following 7 days of pair-feeding (pairfed-100, pairfed-200). Values are means \pm S.E.M. $(n)$

\begin{tabular}{|c|c|c|c|}
\hline & Control & Pairfed-100 ${ }^{1}$ & Pairfed-200 2 \\
\hline Plasma GH (ng/ml) & $0 \cdot 4 \pm 0.04(9)$ & $0.4 \pm 0.04(9)$ & $0 \cdot 5 \pm 0 \cdot 04(8)$ \\
\hline Plasma NPY (ng/ml) & $1 \cdot 0 \pm 0 \cdot 05$ & $0.9 \pm 0.08$ & $1 \cdot 1 \pm 0 \cdot 10$ \\
\hline Hypothalamic NPY (ng/g) & $66 \cdot 3 \pm 6 \cdot 00(9)$ & $61 \cdot 8 \pm 3 \cdot 55(8)$ & $65 \cdot 5 \pm 8 \cdot 50(8)$ \\
\hline
\end{tabular}

Note: pair-fed birds were not infused with GH. For results of GH infusions, see Results and Fig. 2.

${ }^{1}$ Pair-fed to the $100 \mu \mathrm{g} \mathrm{GH} / \mathrm{kg} \mathrm{BW}$ per day dosage group; ${ }^{2}$ pair-fed to the $200 \mu \mathrm{g} \mathrm{GH} / \mathrm{kg}$ BW per day dosage group.

There were no significant differences among groups.

preening behavior and vocalization, water consumption, activity and sleep patterns. Droppings (feces and urine) were normal in consistency, appearance (color) and relative quantity. Internal organs (heart, lungs, liver, kidney and spleen) were normal in appearance/color, texture and lack of abnormal masses.

\section{Effects of pulsatile cGH infusion on circulating $G H$ and FI}

Plasma concentrations of GH were elevated in a dosedependent fashion with $\mathrm{GH}$ infusion, and ranged from $0 \cdot 3 \pm 5 \cdot 7 \mathrm{ng} / \mathrm{ml}$ for controls up to $89 \cdot 0 \pm 5 \cdot 4 \mathrm{ng} / \mathrm{ml}$ at the highest dosage $(200 \mu \mathrm{g} / \mathrm{kg}$ BW per day) (for detailed profile see Vasilatos-Younken et al. 2000). Plasma GH concentrations for pair-fed groups did not differ from controls (Table 1).

Pulsatile infusion of cGH for 7 days had no discernable effect on voluntary FI at the lower dosages administered, but began to depress voluntary FI $(7 \cdot 3 \pm 6 \cdot 3 \%)$ at $100 \mu \mathrm{g} /$ $\mathrm{kg}$ BW per day (Fig. 1). This depression was maximal

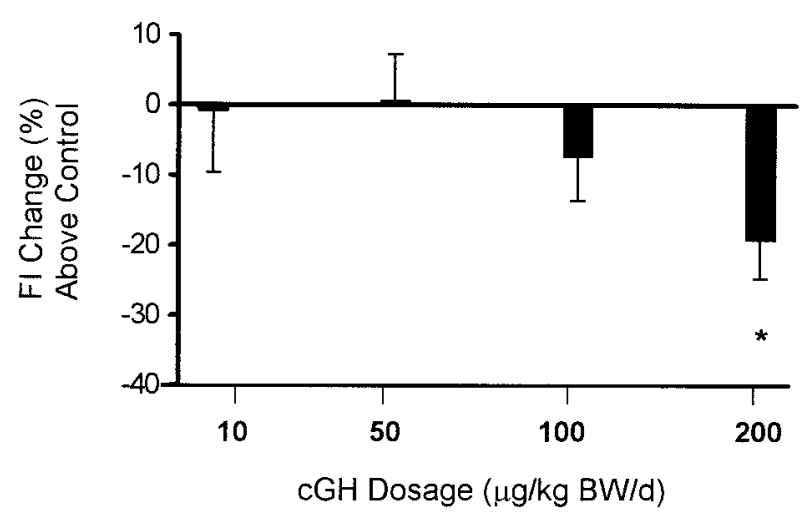

Figure 1 Reduction in voluntary $\mathrm{Fl}$ following pulsatile i.v. GH infusion for 7 days in 8-week-old, female broiler chickens. Each bird served as its own control by calculating the percentage change in average daily $\mathrm{FI}$ (g/kg BW per day) for the final 3 days of infusion, relative to that bird's preinfusion $\mathrm{Fl}$ (average of the 3 days immediately preceding initiation of treatments). Because $\mathrm{FI}$ normally decreases as broilers mature, and this was observed in all birds across treatment groups prior to infusion, Fl change for each $\mathrm{GH}$-treated bird was corrected for the average decline observed in the controls. Values are means \pm S.E.M. $(n=9-10$ birds per dosage). ${ }^{*} P<0 \cdot 05$ compared with pre-infusion FI.
$(19 \pm 5 \cdot 5 \%)$ and significant $(P<0 \cdot 05)$ at the highest dosage $(200 \mu \mathrm{g} / \mathrm{kg} \mathrm{BW}$ per day) administered (Fig. 1).

Effects of pulsatile GH on NPY protein and $m R N A$ levels

The NPY RIA was optimized and validated for determination of plasma and hypothalamic NPY levels in the chicken. Serial dilutions of unknown samples were parallel to the standard curve, and recovery of NPY standard added to Sep-Pak-extracted samples ranged from 95 to $110 \%$ (data not shown). Extraction of hypothalamic samples by elution through C-18 (Sep-Pak) columns improved recovery of NPY at concentrations above $10 \mathrm{ng} / \mathrm{ml}$, and this method was therefore used for preparation of both hypothalamic and plasma samples, as previously reported (Stridsberg \& Lundqvist 1989).

GH $(200 \mu \mathrm{g} / \mathrm{kg}$ BW per day) reduced NPY protein concentration in the hypothalamus compared with controls $(P<0.065)$ (Fig. 2). However, plasma NPY

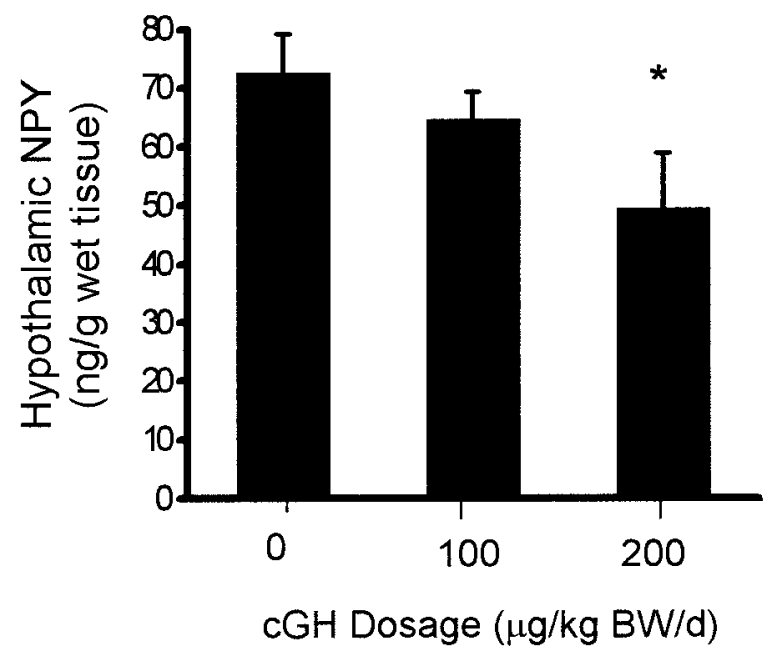

Figure 2 Reduction in hypothalamic NPY following 7 days of pulsatile i.v. cGH infusion in 8-week-old, female broiler chickens. Hypothalamic samples were homogenized in sodium acetate buffer as described in Materials and Methods, and the supernatant was removed for NPY immunoassay. Samples were extracted by elution through $\mathrm{C}_{18}$ (Sep-Pak) columns prior to assay. Values are means \pm S.E.M. $\left(n=9-10\right.$ birds per dosage). ${ }^{*} P=0 \cdot 065$. 


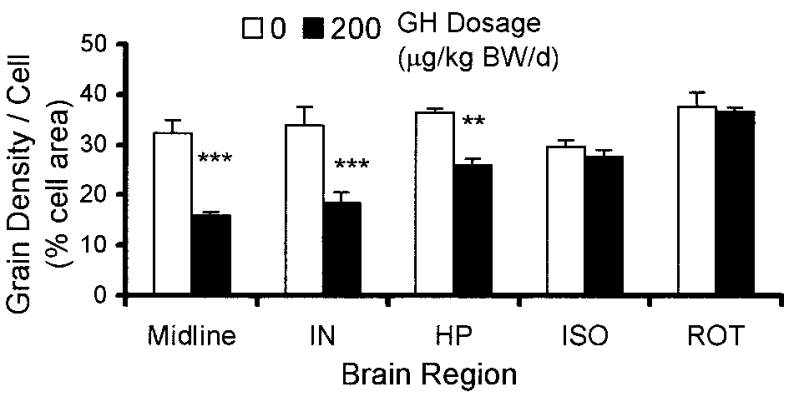

Figure 3 Changes in NPY mRNA in various brain regions (Midline, midline region of the hypothalamus; HP, hippocampus) following pulsatile cGH (200 $\mu \mathrm{g} / \mathrm{kg}$ BW per day) infusion for 7 days in 8-week-old, female broiler chickens. Grain density was expressed as a percentage of the cell area occupied by grains. Background counts were subtracted from each labeled cell count. Values are means \pm S.E.M. ( $n=3-6$ birds/treatment). GH $(200 \mu \mathrm{g} / \mathrm{kg}$ BW per day) treatment resulted in a significant reduction in NPY mRNA in the midline region, IN and HP. ${ }^{* *} P<0 \cdot 01,{ }^{* *} P<0 \cdot 001$ compared with vehicle-infused controls.

concentrations were not affected by GH administration, and averaged 1.0 $\pm 0.05 \mathrm{ng} / \mathrm{ml}$ across all dosages. Both plasma and hypothalamic NPY concentrations in the pair-fed groups were not different from those of the control group (Table 1).

In situ hybridization for NPY message was performed on brain sections from birds of the $\mathrm{GH}$ dosage group that exhibited a significant depression in FI $(200 \mu \mathrm{g} / \mathrm{kg} \mathrm{BW}$ per day), as well as from control and pair-fed groups. At the time this work was conducted, a homologous chicken NPY cDNA was not available. However, a complete map of NPY gene expression in the chicken brain has been generated by our laboratory using the rat pre-proNPY probe used for the present study (X Wang, J R Day \& $\mathrm{R}$ Vasilatos-Younken, unpublished observations) and found to be identical to data independently published for the chicken brain using a chicken riboprobe (Boswell et al. 1998, 1999), and follows the distribution pattern for NPY-containing neurons in the chicken brain based upon previous immunohistochemical studies (Kuenzel \& McMurtry 1988). These would confirm that the rat pre-proNPY riboprobe used for in situ detection in the present study hybridized to NPY mRNA in the chicken brain and accurately represents expression of the gene.

In emulsion-coated sections, NPY mRNA-containing cells were identified by clusters of silver grains over single neurons. Labeling was specific, and silver grains were not observed over cells when sections were hybridized with sense-strand probe (data not shown). Counted cell area for NPY mRNA in various brain regions did not differ among treatments, within region (data not shown).

At the mRNA level, the NPY signal was markedly reduced with GH treatment $(200 \mu \mathrm{g} / \mathrm{kg} \mathrm{BW}$ per day $)$ compared with controls, for both the midline region (PVN and periventricularis nucleus $(\mathrm{PHN}))(50 \% ; P<0 \cdot 0001)$
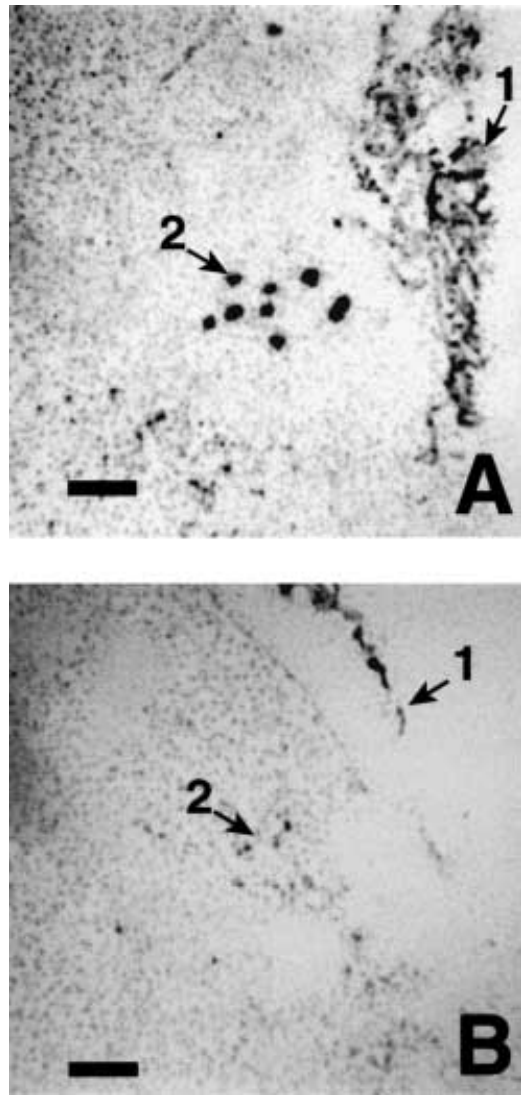

Figure 4 Hypothalamic NPY mRNA expression in the midline region of (A) control and (B) GH-treated $(200 \mu \mathrm{g} / \mathrm{kg}$ BW per day), 8 -week-old, female broiler chickens. Brightfield photomicrographs of chicken brain sections processed for in situ hybridization with ${ }^{35}$ S-labeled riboprobe complimentary to rat pre-proNPY (anti-sense probe), and dipped in photographic emulsion. Grain density (percentage of cell area occupied by labeled grains; indicated by arrows) is reduced in the midline region (arrow 2) of a GH-treated bird (B), in comparison to control (A). No labeling was observed when sections were hybridized with sense-strand probe (not shown). Arrow $1=$ third ventricle. Scale bar $=40 \mu \mathrm{m}$.

and IN of the hypothalamus (46\%; $P<0 \cdot 0001)$ (Figs 3 and 4). NPY mRNA was also significantly reduced in the hippocampus (Fig. 3). There were no significant differences between control and GH-treated groups in the lateral septal organ (LSO) and neurons around the nucleus rotundus (ROT). No significant differences were found in the midline region and IN between control and pair-fed groups (Table 2).

\section{Effects of pulsatile GH on monoamines and their metabolites}

GH decreased hypothalamic EP $(y=1253-1 \cdot 83 x$, $P=0 \cdot 009$, coefficient of determination $(\mathrm{R}-\mathrm{Sq})=0 \cdot 227)$ (Table 3). The maximal effect was at $200 \mu \mathrm{g} / \mathrm{kg} \mathrm{BW}$ per day, at which hypothalamic EP concentrations were reduced $37 \%$ versus vehicle-infused. DOPAC was 
Table 2 NPY mRNA (grain density; \% of total cell area) in the midline and IN region of the brain following 7 days of pair-feeding (pairfed-200) in 8-week-old broiler chickens. Values are means \pm S.E.M. $(n)$

\begin{tabular}{|c|c|c|}
\hline & Treatment & \\
\hline & Control & Pairfed-200 ${ }^{1}$ \\
\hline Midline $^{2}$ & $20 \cdot 3 \pm 1 \cdot 30$ & $19 \cdot 0 \pm 1 \cdot 39$ \\
\hline IN & $25 \cdot 9 \pm 1 \cdot 85$ & $22 \cdot 9 \pm 1 \cdot 42$ \\
\hline
\end{tabular}

Note: pair-fed birds were not infused with GH. For results of GH infusion, see Results and Fig. 3.

${ }^{1}$ Pair-fed to the $200 \mu \mathrm{g} \mathrm{GH} / \mathrm{kg}$ BW per day dosage group.

${ }^{2} \mathrm{PVN}$ and PHN.

Control and pair-fed groups did not differ.

significantly decreased after 7 days of $\mathrm{GH}$ treatment $(y=1189 \cdot 3-2 \cdot 16 x, \quad P=0 \cdot 025, \quad \mathrm{R}-\mathrm{Sq}=0 \cdot 107) . \quad$ The DOPAC/DA ratio, which is an indicator of DA turnover, was significantly decreased as GH dosage increased $(y=2 \cdot 28-0.00374 x, \quad P=0.007, \quad \mathrm{R}-\mathrm{Sq}=0 \cdot 251), \quad$ even though hypothalamic DA was not significantly affected by $\mathrm{GH}$ treatment. GH had no effect on other hypothalamic monoamines and metabolites (5-HT, HVA, NE and DA/HVA). No significant differences were observed in pair-fed groups for all monoamines measured in the hypothalamus (data not shown).

A GH dose-related increase in the DOPAC/DA ratio in the medulla was observed $(\gamma=3 \cdot 26+0 \cdot 05 x, P=0 \cdot 015$, $\mathrm{R}-\mathrm{Sq}=0.287$ ) (Table 4). Significant increases in 5-HIAA and DA were not dose-related, but were observed for the $10 \mu \mathrm{g} \mathrm{cGH} / \mathrm{kg} \mathrm{BW}$ per day treatment dosage compared with the control group $(P<0 \cdot 05)$. No differences were observed for other monoamines (Table 4). Feed restriction had no significant effect on any of the monoamines or their metabolites measured in the medulla (data not shown).

\section{Discussion}

The present study was conducted to assess the influence of a physiologically relevant pattern of $\mathrm{GH}$ enhancement (pulsatile i.v. infusion) on FI, and possible mechanisms underlying this effect, using an animal model that exhibits relatively high levels of feed consumption. The appetitedepressive effect of GH over a range of dosages was assessed, beginning at an age when endogenous $\mathrm{GH}$ secretion is low relative to earlier ages. Because of the precise control possible with microprocessor-controlled, intravenous delivery, circulating concentrations of $\mathrm{GH}$ achieved over the full dose-response curve were extremely uniform within dosage groups, and nonoverlapping among groups. With this model, a significant depression in voluntary FI was detected only at the highest peak plasma concentration achieved (i.e. at $200 \mu \mathrm{g} \mathrm{GH} / \mathrm{kg}$ BW per day).
In conjunction with decreased FI, GH administration resulted in a dramatic reduction in hypothalamic NPY protein and gene expression, supporting the idea that regulation is at a pre-translational level. Further, as intracerebral injection of NPY induces a robust increase in FI in the chicken (Kuenzel et al. 1987b), decreased NPY may mediate the anorexia caused by GH, possibly by increasing sympathetic nervous system activity (Stanley 1993). A large body of evidence suggests that NPY of hypothalamic origin, produced primarily in the IN (equivalent to the mammalian arcuate nucleus) of the hypothalamus, may be involved in the control of ingestive behavior in the chicken. In this study, NPY mRNA was depressed in both the IN and midline regions (PVN and PHN) of the hypothalamus, as well as in the hippocampus. Although the hippocampus may participate in the regulation of FI (Davidson \& Jarrard 1993), the exact roles of hippocampal NPY on FI are unclear.

In contrast to the response observed in chickens in the present study, GH up-regulates NPY mRNA in the hypothalamus of the rat (Kamegai et al. 1994, Chan et al. 1996). This species-specific difference may explain the difference in FI response to GH in the rat versus chicken (and other species that respond similarly to the latter, such as the human).

The values presented here for concentrations of NE and DA in the hypothalamus and in the medulla agree well in general with available data for the chick (Kuenzel et al. 1987b, Siuciak et al. 1992). 5-HT and 5-HIAA levels in this study are in agreement with previous studies in the chicken brain using HPLC analysis (Cassone et al. 1986, Siuciak et al. 1992). Our data for EP, however, were ten times higher than those found by Siuciak et al. (1992), and much higher than those reported by Kuenzel et al. (1987b). It is unlikely that these differences are methodologic, as concentrations of other monoamines were similar across studies. Rather, these differences may be due to neurodevelopmental stage, as juvenile (8-week-old) birds were used in the present study, versus infant (2-week-old chicks) previously (Kuenzel et al. 1987b, Siuciak et al. 1992).

$\mathrm{GH}$ significantly depressed EP in a dose-dependent manner in the hypothalamus. This is consistent with reports that synthesis and release of catecholamines are reduced after bolus $\mathrm{GH}$ administration both in the rat (Stern et al. 1975) and in the chicken (Lea \& Harvey 1993). EP has been shown to increase FI in the chicken (Denbow et al. 1981). The reduction in EP may therefore contribute to the FI-depressive effect of $\mathrm{GH}$ as well. Given that a close anatomical association between the adrenergic and NPY neural systems exists (Sawchenko et al. 1985), and stimulation of feeding induced by central administration of NPY can be attenuated by prior blockade of $\alpha 2$ adrenoceptors (Clark et al. 1988), it is possible that EP may, at least partially, mediate the effect of NPY on feeding behavior. 
Table 3 Effect of pulsatile i.v. infusion of $\mathrm{GH}$ for 7 days on monoamines and their metabolites in the chicken hypothalamus (pg/mg tissue). Values are means \pm S.E.M. $(n)$

cGH dosage $(\mu \mathrm{g} / \mathrm{kg}$ BW per day)

\begin{tabular}{|c|c|c|c|c|c|}
\hline \multicolumn{6}{|l|}{ Measurement } \\
\hline NE & $1987 \pm 344(9)$ & $1719 \pm 222(9)$ & $1849 \pm 299(9)$ & $1589 \pm 196(9)$ & $1745 \pm 278(6)$ \\
\hline 5-HT & $923 \pm 107$ & $874 \pm 123$ & $872 \pm 101$ & $873 \pm 107(10)$ & $1061 \pm 119(10)$ \\
\hline 5 -HIAA & $820 \pm 54(9)$ & $912 \pm 94(9)$ & $885 \pm 48(9)$ & $847 \pm 52(9)$ & $897 \pm 76(10)$ \\
\hline 5-HIAA/5-HT & $0 \cdot 98 \pm 0 \cdot 13(9)$ & $1 \cdot 16 \pm 0 \cdot 16(9)$ & $1 \cdot 12 \pm 0 \cdot 14(9)$ & $0 \cdot 97 \pm 0 \cdot 10(8)$ & $0 \cdot 82 \pm 0 \cdot 10(9)$ \\
\hline HVA/DA & $4 \cdot 60 \pm 0 \cdot 22(7)$ & $4.65 \pm 0.52(7)$ & $4 \cdot 41 \pm 0.53$ & $6 \cdot 10 \pm 1 \cdot 54(6)$ & $4 \cdot 18 \pm 0 \cdot 19(7)$ \\
\hline DOPAC $^{*}$ & $1050 \pm 113(6)$ & $983 \pm 90(9)$ & $908 \pm 79(9)$ & $927 \pm 70(10)$ & $829 \pm 83(10)$ \\
\hline DOPAC/DA** & $2 \cdot 72 \pm 0 \cdot 15(6)$ & $1.95 \pm 0.23$ & $1 \cdot 71 \pm 0 \cdot 24(5)$ & $1.95 \pm 0.23$ & $1 \cdot 59 \pm 0.14(7)$ \\
\hline
\end{tabular}

${ }^{*} P<0 \cdot 05,{ }^{* *} P<0 \cdot 01$; significant linear regression.

Although hypothalamic DA was unaffected by GH, the DOPAC/DA ratio was significantly decreased in the hypothalamus. This result is consistent with reduced DA turnover in the hypothalamus in $\mathrm{GH}$ transgenic mice (Steger et al. 1991). In the medulla, GH affected DA turnover in the opposite direction. Given that injection of DA into the lateral ventricle has no effect on FI in the chick (Denbow et al. 1981), the change in DA metabolism observed in this study may not be relevant to GH-induced FI depression.

Feed restriction per se was reported to increase levels of NPY mRNA and protein (Sahu et al. 1988) and 5-HT content (Krieger 1974) in the hypothalamus of the rat, and $48 \mathrm{~h}$ of feed deprivation has been reported to decrease hypothalamic NE and DA levels (Stachowiak et al. 1979). In the present study, feed restriction imposed on birds pair-fed to the reduced level of the GH treatment group had no effect on hypothalamic NPY protein and mRNA concentrations and monoamine levels, possibly because the level of restriction was not comparably severe to the previous studies cited above. However, more importantly, these strongly support that the changes associated with $\mathrm{GH}$ treatment are not secondary to the reduced FI that accompanies higher dosages of the hormone.

It is not clear whether the reduction in NPY and EP in response to $\mathrm{GH}$ administration is a direct effect on the hypothalamus or via a secondary mediator. Most of the NPY-containing neurons in the arcuate nucleus have been shown to express GH receptor mRNA (Chan et al. 1996). Since there is evidence that $\mathrm{GH}$ is able to cross the blood-brain barrier (Tannebaum \& Ling 1980), it is possible that GH may regulate the activity of NPY neurons in the hypothalamus directly.

Alternatively, companion data from this study demonstrate that GH increases hepatic leptin mRNA in a dose-dependent manner, whereas leptin gene expression is depressed with feed restriction per se, as was observed in the pair-fed group (Ashwell et al. 1999). Leptin is a

Table 4 Effect of pulsatile i.v. infusion of $\mathrm{GH}$ for 7 days on monoamines and their metabolites in the chicken medulla (pg/mg tissue). Values are means \pm S.E.M. $(n)$

cGH dosage $(\mu \mathrm{g} / \mathrm{kg}$ BW per day)

\begin{tabular}{|c|c|c|c|c|c|}
\hline & 0 & 10 & 50 & 100 & 200 \\
\hline \multicolumn{6}{|l|}{ Measurement } \\
\hline NE & $1419 \pm 194$ & $1303 \pm 129$ & $1354 \pm 128$ & $1432 \pm 333(10)$ & $1628 \pm 362(10$ \\
\hline $\mathrm{EP}$ & $1122 \pm 368$ & $507 \pm 94(4)$ & $917 \pm 199$ & $602 \pm 118$ & $1207 \pm 388$ \\
\hline $5-\mathrm{HT}$ & $450 \pm 97(8)$ & $456 \pm 95(8)$ & $398 \pm 109(9)$ & $434 \pm 68(9)$ & $674 \pm 144(9)$ \\
\hline 5-HIAA & $468 \pm 56(9)$ & $678 \pm 44(8)$ & $616 \pm 83(10)$ & $650 \pm 71(10)$ & $523 \pm 53(9)$ \\
\hline 5-HIAA/5-HT & $1 \cdot 14 \pm 0 \cdot 19(8)$ & $1 \cdot 59 \pm 0 \cdot 28(7)$ & $2 \cdot 74 \pm 0 \cdot 74(9)$ & $2 \cdot 37 \pm 0 \cdot 85(9)$ & $2 \cdot 62 \pm 1.43(9)$ \\
\hline DA & $293 \pm 38(5)$ & $400 \pm 15(5)$ & $317 \pm 28(6)$ & $400 \pm 46(3)$ & $264 \pm 29(5)$ \\
\hline HVA & $1834 \pm 96(8)$ & $2071 \pm 121$ & $1779 \pm 97(9)$ & $1026 \pm 142(10)$ & $1619 \pm 161$ \\
\hline HVA/DA & $6 \cdot 34 \pm 0 \cdot 75$ & $5 \cdot 57 \pm 0.37(5)$ & $6 \cdot 10 \pm 0.57(6)$ & $5 \cdot 87 \pm 0 \cdot 23(3)$ & $6 \cdot 26 \pm 0 \cdot 28(5)$ \\
\hline DOPAC & $867 \pm 135(7)$ & $3072 \pm 953(7)$ & $1487 \pm 490(7)$ & $1327 \pm 464(10)$ & $2763 \pm 1005$ \\
\hline DOPAC/DA* & $2.54 \pm 0.56$ & $6 \cdot 21 \pm 2 \cdot 44$ & $5 \cdot 39 \pm 2.99$ & $5 \cdot 23 \pm 1 \cdot 72(3)$ & $14.97 \pm 4.95$ \\
\hline
\end{tabular}

${ }^{*} P<0 \cdot 05$; significant linear regression. 
peripheral signal informing the brain of starvation (Ahima et al. 1996). Among several possible mediators of leptin action within the hypothalamus, NPY is the most important (Erickson et al. 1996). Since mice that lack NPY still respond normally to the satiety effects of leptin, other mediators of leptin must exist within the brain. The depressive effect of GH on FI may be due to changes in peripheral leptin production. Leptin in turn may induce changes in hypothalamic NPY (and possibly EP), which result in anorexia.

Our results verify that pulsatile infusion of $\mathrm{GH}$ for 7 days, at a dosage that achieved a high physiological peak amplitude concentration of the hormone, significantly suppressed FI, and suggest that NPY and EP are involved in this effect. The reduction in both NPY and EP could account for the sustained depressive effects of GH on feeding, as EP has very brief latencies and short-acting effects (1-30 min), while NPY has long-term effects (up to 4 h) (Stanley et al. 1986). Future research is required to confirm whether the effects of GH on hypothalamic NPY and $\mathrm{EP}$ are direct, or if secondary mediators are involved.

\section{Acknowledgements}

The authors wish to thank B J Andersen, D Pinero and $\mathrm{K}$ Erikson for their technical advice and assistance with sample collection and analysis. This work was partially supported by a grant from DeGussa Corp., Kennesaw, GA, USA and USDA-NRI grant no. 98-35206-6411 to R V-Y.

\section{References}

Ahima RS, Prabakaran D, Mantzoros C, Qu D, Lowell B, MaratosFlier EP \& Flier JS 1996 Role of leptin in the neuroendocrine response to fasting. Nature 382 250-252.

Allen R, Boublik J, Hauger RL, Scott N, Rivier J \& Brown MR 1991 Neuropeptide $Y$ radioimmunoassay: characterization and application. Clinical and Experimental Pharmacology and Physiology 18 825-833.

Ashwell CM, McMurtry JP, Wang X-H, Zhou Y \& VasilatosYounken R 1999 Effects of growth hormone and pair-feeding on leptin mRNA expression in liver and adipose tissue. Domestic Animal Endocrinology 17 77-84.

Azain MJ, Roberts TJ, Martin RJ \& Kasser TR 1995 Comparison of daily versus continuous administration of somatotropin on growth rate, feed intake, and body composition in intact female rats. Journal of Animal Science 73 1019-1029.

Blomqvist AG, Soderberg C, Lundell I, Milner RJ \& Larhammar D 1992 Strong evolutionary conservation of neuropeptide Y: sequences of chicken, goldfish, and Torpedo marmorata DNA clones. PNAS 89 2350-2354.

Boswell T, Millam JR, Li Q \& Dunn IC 1998 Cellular localization of neuropeptide $\mathrm{Y}$ mRNA and peptide in the brain of the Japanese quail and domestic chicken. Cell and Tissue Research 193 31-38.

Boswell T, Dunn IC \& Corr SA 1999 Hypothalamic neuropeptide Y mRNA is increased after feed restriction in growing broilers. Poultry Science 78 1203-1207.
Cassone VM, Lane RF \& Menaker M 1986 Melatonin-induced increases in serotonin concentrations in specific regions of the chicken brain. Neuroendocrinology 42 38-43.

Chan YY, Steiner RA \& Clifton DK 1996 Regulation of hypothalamic neuropeptide-Y neurons by growth hormone in the rat. Endocrinology 137 1319-1325.

Clark JT, Gist RS \& Kalra PS 1988 Alpha 2-adrenoceptor blocade attenuates feeding behavior induced by neuropeptide $\mathrm{Y}$ and epinephrine. Physiology and Behavior 43 417-422.

Cravener TL \& Vasilatos-Younken R 1989 A method for catheterization, harnessing and chronic infusion of undisturbed chickens. Laboratory Animals 23 270-274.

Davidson TL \& Jarrard LE 1993 A role for hippocampus in the utilization of hunger signals. Behavioral and Neural Biology 59 167-171.

Day JR, Laping NJ, McNeill TH, Schreiber SS, Pasinetti G \& Fincher CE 1990 Castration enhances expression of glial fibrillary acidic protein and sulfated glycoprotein-2 in the intact and lesionaltered hippocampus of the adult male rat. Molecular Endocrinology 4 1995-2002.

Denbow DM 1985 Food intake control in birds. Neuroscience and Biobehavioral Reviews 9 223-232.

Denbow DM, Cherry JA, Siegel PB \& Van Krey HP 1981 Eating, drinking and temperature response of chicks to brain catecholamine injections. Physiology and Behavior 27 265-269.

Erickson JC, Hollopeter G \& Palmiter RD 1996 Attenuation of the obesity syndrome of ob/ob mice by the loss of neuropeptide Y. Science 274 1704-1707.

Higuchi H, Yang HY \& Sabol SL 1988 Rat neuropeptide Y precursor gene expression, mRNA structure, tissue distribution and regulation by glucocorticoids, cyclic AMP and phorbol ester. Journal of Biological Chemistry 263 6288-6295.

Hunter WM \& Greenwood FC 1962 Preparation of iodine-131 labelled human growth hormone of high specific activity. Nature 194 495-496.

Johnson RJ, Fairclough RJ \& Cahill LP 1987 Temporal secretary patterns of growth hormone in young meal-type poultry. British Poultry Science 28 103-111.

Kamegai J, Minami S, Sugihara H, Hasegawa O, Higuchi H \& Wakabayashi I 1994 Growth hormone induces expression of the c-fos gene on hypothalamic neuropeptide-Y and somatostatin neurons in hypophysectomized rats. Endocrinology 135 2765-2771.

Klindt J, Yen JT, Buonomo FC, Roberts AJ \& Wise T 1998 Growth, body composition and endocrine responses to chronic administration of insulin-like growth factor I and porcine growth hormone in pigs. Journal of Animal Science 76 2368-2381.

Krieger DT 1974 Food and water restriction shifts corticosterone, temperature, activity and brain amine periodicity. Endocrinology 95 1195-1201.

Kuenzel WJ \& McMurtry JP 1988 Neuropeptide Y: brain localization and central effects on plasma insulin levels in chicks. Physiology and Behavior 44 669-678.

Kuenzel WJ \& Masson M 1988 A Sterotaxic Atlas of the Brain of the Chick (Gallus domesticus). Baltimore: The Johns Hopkins University Press.

Kuenzel WJ, Snapir N \& Rexroad CE Jr 1987a Food intake and biogenic amine concentrations in brain regions of chicks following intracerebroventricular injection of six-hydroxydopamine. Pharmacology, Biochemistry and Behavior 27 257-263.

Kuenzel WJ, Douglass LW \& Davison BA $1987 b$ Robust feeding following central administration of neuropeptide Y or peptide YY in chicks, Gallus domesticus. Peptides 8 823-828.

Lea RW \& Harvey S 1993 Growth hormone (GH) suppression of catecholamine turnover in the chicken hypothalamus: implications for GH autoregulation. Journal of Endocrinology 136 245-251. 
Leibowitz SF 1980 Neurochemical systems of the hypothalamus: control of feeding and drinking behavior and water-electrolyte excretion. In Handbook of the Hypothalamus, vol 3A, pp 299-437. New York: Marcel Dekker.

Leibowitz SF 1985 Brain neurotransmitters and appetite regulation. Psychopharmacology Bulletins 21 412-418.

Leibowitz SF 1989 Hypothalamic neuropeptide Y, galanin, and amines. Concepts of coexistence in relation to feeding behavior. Annals of the New York Academy of Sciences 575 221-233.

Leibowitz SF \& Brown LL 1980 Histochemical and pharmacological analysis of noradrenergic projections to the paraventricular hypothalamus in relation to feeding stimulation. Brain Research 201 289-314.

McDonald JK 1988 NPY and related substances. Critical Reviews in Neurobiology 4 97-135.

National Research Council (US) 1994 Nutrient Requirements of Poultry. Subcommittee on Poultry Nutrition, p 14. Washington DC: National Academy of Sciences.

Pym PAE \& Nicholls PJ 1979 Selection for food conversion in broilers: direct and correlated responses to selection for body-weight gain, food consumption, and food conversion ratio. British Poultry Science 20 73-86.

Sahu A, Kalra PS \& Kalra SP 1988 Food deprivation and ingestion induce reciprocal changes in neuropeptide $\mathrm{Y}$ concentrations in the paraventricular nucleus. Peptides 9 83-86.

Sawchenko PE, Swanson LW, Grzanna R, Howe PR, Bloom SR \& Polak JM 1985 Co-localization of neuropeptide Y immunoreactivity in brainstem catecholaminergic neurons that project to the paraventricular nucleus of the hypothalamus. Journal of Comparative Neurology 241 138-153.

Siegel P \& Wisman EL 1966 Selection for body weight at eight weeks of age. 6. Changes in appetite and feed utilization. Poultry Science $\mathbf{4 5}$ 1131-1397.

Siuciak JA, Gamache PH \& Dubocovich ML 1992 Monoamines and their precursors and metabolites in the chicken brain, pineal, and retina: regional distribution and day/night variations. Journal of Neurochemistry $\mathbf{5 8} 722-729$.

Stachowiak M, Bialowas J, Jurkowski MK \& Mirosz J 1979 Hunger induced changes in the noradrenaline and dopamine contents in various nuclei of the limbic system in rats. Polish Journal of Pharmacology and Pharmacy 31 337-343.

Stanley BG 1993 Neuropeptide Y in multiple hypothalamic sites controls eating behavior, endocrine, and autonomic systems for body energy balance. In The Biology of Neuropeptide Y and Related Peptides, pp 457459. Eds WF Colmers \& C Walestedt. Totowa, NJ: Humana Press.

Stanley BG, Kyrkouli SE, Lampert S \& Leibowitz SF 1986 Neuropeptide Y chronically injected into the hypothalamus: a powerful neurochemical inducer of hyperphagia and obesity. Peptides 7 1189-1192.
Steger RW, Bartke A, Parkening TA, Collins T, Buonomo FC, Tang KC, Wagner TE \& Yun JS 1991 Effects of heterologous growth hormones on hypothalamic and pituitary function in transgenic mice. Neuroendocrinology 53 365-372.

Stern WC, Miller M, Jalowiec JE, Forbes WB \& Morgane PJ 1975 Effects of growth hormone on brain biogenic amine levels. Pharmacology, Biochemistry and Behavior 3 1115-1118.

Stridsberg M \& Lundqvist G 1989 Radioimmunoassay of neuropeptide Y (NPY) in biological fluids. Circulating NPY levels depend on renal function. Clinica Chimica Acta 185 61-72.

Tannebaum GS \& Ling N 1980 The interrelationship of growth hormone $(\mathrm{GH})$-releasing factor and somatostatin in generation of the ultradian rhythm of GH secretion. Endocrinology 115 1952-1957.

Vaccarino FJ, Kennedy SH, Ralevski EP \& Black R 1994 The effects of growth hormone releasing factor on food consumption in anorexia nervosa patients and normals. Biological Psychiatry 35 446-451.

Vasilatos-Younken R 1986 Preparation and culture of dispersed avian pituitary cells, and age-related changes in donor pituitary weight and growth hormone content. General and Comparative Endocrinology 64 99-106.

Vasilatos-Younken R 1995 Proposed mechanisms for the regulation of growth hormone action in poultry: metabolic effects. Journal of Nutrition 125 1783S-1789S.

Vasilatos-Younken R \& Zarkower PG 1987 Age-related changes in plasma immunoreactive growth hormone secretory patterns in broiler pullets. Growth $\mathbf{5 1} 171-180$.

Vasilatos-Younken R, Cravener TL, Cogburn LA, Mast MG \& Wellenreiter RH 1988 Effect of pattern of administration on the response to exogenous pituitary-derived chicken growth hormone by broiler-strain pullets. General and Comparative Endocrinology $\mathbf{7 1}$ 268-283.

Vasilatos-Younken R, Zhou Y, Wang X, McMurtry JP, Rosebrough RW, Decuypere E, Buys N, Darras VM, Van der Geyten S \& Tomas F 2000 Altered chicken thyroid hormone metabolism with chronic GH enhancement in vivo: consequences for skeletal muscle growth. Journal of Endocrinology 166 609-620.

Yang ZJ, Meguid MM, Chai JK, Chen C \& Oler A 1997 Bilateral hypothalamic dopamine infusion in male Zucker rat suppresses feeding due to reduced meal size. Pharmacology, Biochemistry and Behavior 58 631-635.

Received 20 October 1999

Revised manuscript received 20 January 2000 Accepted 26 April 2000 